\title{
Central Java's assault on media ethics How the Governor turned watchdogs into pet poodles
}

\begin{abstract}
This study examines the coverage of Indonesia's main newspaper Suara Merdeka and Radar Semarang (Jawa Pos group) about the Governor of Central Java, Ganjar Pranowo, in 2016, during his mid-term period in leading the province. It highlights how the Governor, who initially removed help for journalists, became a figure that journalists like. The qualitative content analysis of 20 articles that took part in the journalism competition for journalists held by the Public Relations Bureau Regional Secretary of Central Java Province showed that the news stopped at Ganjar Pranowo without trying to find deeper meaning from the field. The news frames used by the newspapers reflected that journalists who are members of the Press Club at the Public Relations Bureau of Central Java Province were reluctant to be critical toward Ganjar Pranowo. Ganjar Pranowo was portrayed solely in the context of his success in leading Central Java based on assumptions made by journalists. The newspaper is no longer a neutral agent, but is rather tendentious. Unlike in some other countries, in Indonesia's Central Java the press club is not beneficial for the development of democracy and the establishment of journalists.
\end{abstract}

Keywords: content analysis, democracy, Indonesia, journalists, journalism competition, news coverage, news frames, press clubs

\section{ANA NADHYA ABRAR \\ Universitas Gadjah Mada, Yogyakarta}

\section{Introduction}

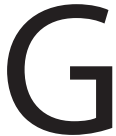

ANJAR PRANOWO was appointed Governor of Central Java on 23

August 2013. Since then, he has shocked various parties. By implementing the principle of 'Mboten Korupsi-Mboten Ngapusi' ('No Corruption-No Lie'), he broke the establishment of the Central Java Regional Government bureaucracy. He also stopped aid for journalists. Regarding this last move, Isdiyanto said:

Starting from the issue of termination for a number of journalist communities and journalist organisations, including the policy of eliminating 'envelopes' as transport coverage of Central Java Provincial Government 
until the arrest of thousands of social assistance for educational and religious institutions also led to polemics. (2016, p. viii)

Of course, Ganjar Pranowo became unpopular. However, he did not care about his popularity. He continued to implement his policies, which he considered to be correct. When he had a chance to explain the reasons behind his attitude, Ganjar said he carried out his policies in order to create a 'clean government'. The reason as described by Isdiyanto was as follows:

The cessation of assistance to the journalist community and the elimination of envelopes was based on the notion that the tradition was not healthy for the professionalism of the press. The deferral of disbursement of social assistance grants is because, after being researched, many are fictitious, marked up, marked down, and deductible. (2016, p. viii)

Presumably Ganjar thought that the explanation could cool down the atmosphere. Apparently he was mistaken. The conflict between him and the journalists became even hotter, as Isdiyanto narrated:

Even hot conflicts and polemics between Ganjar as Governor and various parties are inevitable. There are still many elements that have not fully understood the background of the policy. (2016, p. viii)

However, Ganjar remains unshakeable. He still makes policies in accordance with the values that he believes to be true. Are the policies wrong? If he makes and carries out a wrong policy, it will certainly affect his credibility as governor. If his credibility decreases, actually he is not building his future as governor.

Actually, Ganjar Pranowo does not want to confront journalists. Instead, he wants to develop journalists' optimal potential. In this context, he has held a journalism competition for all journalists who were members of the Press Club of the Public Relations Bureuau of Central Java Province. The competition has been held every year since 2013.

This competition actually co-opted journalists. Journalists no longer dare to criticise Ganjar. Press accountability is even handed over to Ganjar. This situation is happening a lot in Indonesia. Lessons from the case of the Press Club and the Public Relations Bureau of Central Java Province need to be heeded. From this case, it is possible to formulate how the relations between the press club and the provincial government should be established. If this formula cannot be adopted, the quality of the press will get worse and it will be abandoned by its readers.

This study examines the coverage of Indonesia's main newspaper Suara Merdeka and its web edition, Radar Semarang (Jawa Pos group), about the Governor of Central Java, Ganjar Pranowo, in 2016, during his halfway period in leading the province. 


\section{Literature review}

\section{The history of the press club}

Journalism history is one of an evolving, developing profession which is always pursuing collective autonomy. Dickinson and Memon argue that:

press clubs were initially conceived as associations in which journalists could establish and strengthen their sense of occupational group membership and assert their collective interests with regard to newspaper owners and publishers. $(2012$, p. 3$)$

One of the characteristics of an evolving occupation is the urge to create professional associations of various sorts, and the formation of journalism seems always to entail the establishment of occupational associations and/or trade unions. Krause notes how, by the late nineteenth century, US journalists had developed their own 'forms of sociality' in the shape of press clubs (2011, p. 84). According to Dickinson and Memon, journalists need to form a press club to accommodate their various needs, such as in the case of the Birmingham Press Club, which

having been established (as the Junior Pickwick Club) in 1865, claims to be the oldest in the world, and is a focus for local media award ceremonies, commemorative lunches, and a programme of invited speakers. (2012, p. 3)

In Asia, one of the largest press clubs is the Nippon Kisha Club (Japan National Press Club). It is a non-profit organisation that was established on 1 November 1969. Osamu Asano described the job of the press club as follows:

The club holds press luncheons, press conferences and study sessions on various subjects, inviting prominent foreign and Japanese important news sources figures. It has firmly established its positions and reputation as a site from which state guests, officials and other important visitors to Japan-heads of state, prime ministers and other Cabinet ministers-and their views to the Japanese people and workdwide audiences. (1996, p. 65)

This quote shows that the press club in Japan is autonomous and not on the side of the speaker who spoke. It does not even represent the interests of any political authority.

In Pakistan, the press club system helps journalists to pursue their selfinterest. This is a reminder that, to understand news production and journalism and how they are performed and accomplished, it must be acknowledged that they are forms of social organisation that are historically, culturally and socially situated (Dickinson \& Memon, 2012). 


\section{The press club in Indonesia}

The idea of establishing a press club in Indonesia emerged after the New Order era. Regardless of agreeing or not with the idea, President Suharto encouraged and stimulated each ministry to establish a press club. In this case, each ministry assigns a public relations department to prepare various facilities for journalists, starting from offices, computers, fax, drinks and so on. So the reporter covering the ministry is based there every day. They just receive the information conveyed by public relations officers. They feel indebted. Therefore, they are no longer critical of the ministry.

This situation continued until the Reformation Era. Even though the atmosphere has changed, the press club position has been retained. This situation was replicated by all provinces in Indonesia.

With the presence of a press club, the government imagines that news about the results of development carried out by each ministry can immediately reach the public. The press has no difficulty in gathering information about development results. Apparently, there was a negative impact that the government had never imagined. These negative impacts, according to Kuga (2016) include: 1) the press club makes journalists cooperate with each other, even though they work at rival companies (encouraging the final feature) and 2) journalists from different companies sometimes have a brief meeting to check information together at the press club and come to a common understanding.

The reality that occurred at the Press Club of Central Java was not like this. The members of the press club wrote the same stories about Central Java Province, without critically engaging with their information. They framed the news that under the leadership of Ganjar Pranowo, everything was fine in the province of Central Java.

Ideally, the duty of a journalist is to be a watchdog for the community. $\mathrm{He} /$ she helps people to see phenomena in more detail. He/she choses to provide uniform news in order to make the press club happy instead. He/she always puts the truth at the highest position. If this is the case, where is the ideal journalist? Then what is the ideal journalist? What is meant by a great journalist?

\section{The great journalist}

According to UNESCO the majority of journalists aim 'to serve society by informing the public, scrutinising the way power is exercised, stimulating democratic debate, and in those ways aiding political, economic, social, and cultural development' (2007, p. 7). In class, student journalists must follow some criteria that lead them to become a great journalist. Knowledge, experience, and skills are important in journalism education, but in practice attitude is also important (Ismail \& Ismail, 2017). Ismail and Ismail pointed out that journalism was not only a skill. They stated as follows: 
The understanding of journalism is not as a skill but as social, cultural, and philosophical expression, and general education is needed to cover the journalistic aspect of life. (2017, p. 148)

The criteria of a great journalist, according to Abrar, include: 1) being expert in applying the values and mission of journalism; 2) being skilled in writing news that is widely accepted by the public, both quantitatively and qualitatively; 3) having outstanding achievements and work abilities strikingly over a long period of time; 4) having noble ideals about his/her profession and try to achieve these goals; and 5) being proficient in being meaningful to the audience (1997, p. 59). This criteria indicates that the achievement of a great journalist is really because of hard work.

However, when a journalist participates in a journalism competition, there must be a desire to be a winner. A winner is already on the road to becoming a great journalist. The problem is, do the judges use universal criteria about good and true journalism?

Another question is: what are the criteria for universal good news? According to Azi, the universal criteria are the right news for audiences who deliberately choose the press (1992, p. i). That is why press has a target audience of up to three levels, such as the main target, the second goal and the third goal. When all target audiences are satisfied by the news broadcast or publication, it means the news is good.

Then how is the relationship between the media and officials reported? According to Lance Bennett (cited in Abrar, 1997) four criteria apply: 1) is there a tendency to concentrate on the news reported by the officials, not on the issues being reported; 2) is there an impression that the information reported was obtained by

\section{Table 1: News quality assessment sheet}

\begin{tabular}{|l|l|l|l|}
\hline No. & \multicolumn{1}{|c|}{ Aspect } & Comment & Writing in paragraphs \\
\hline 1 & $\begin{array}{l}\text { The tendency of the news to be concen- } \\
\text { trated on the government officials report- } \\
\text { ed was not on the issue being reported. }\end{array}$ & & \\
\hline 2 & $\begin{array}{l}\text { The impression that the information } \\
\text { reported was obtained by journalists in a } \\
\text { very easy way. }\end{array}$ & $\begin{array}{l}\text { News that is broadcast contains infor- } \\
\text { mation that stands alone, not related to } \\
\text { similar issues in the past and future. }\end{array}$ & \\
\hline 4 & $\begin{array}{l}\text { News coverage stops with officials as } \\
\text { resource persons without trying to find } \\
\text { a deeper meaning from the unofficial } \\
\text { sources. }\end{array}$ & & \\
\hline
\end{tabular}


journalists in a very simple way; 3 ) does the news broadcast/publication contain stand alone information; and 4) does the reporting only apply to officials as resource people without trying to find deeper meaning from unofficial sources (Bennett, as cited in Abrar, 1997, p. 23). If the answers to all the questions are yes, then the news broadcast/publication will prioritise the interests of the government official.

This fact teaches us that news is not just a report that was, is and will happen. There is something in the news. Sometimes even the implied meaning is more important than the actual news. That is why audiences are required not only to read the explicit news, but also the implicit writing. In the meantime, the obligation of the media to present news shows that the press must serve the public. As a public servant, the media needs to account for the 'servant'. It has accountability. The problem is how should it carry out its accountability?

According to Abrar, there are at least two things that need to be considered. First, the media need to have an awareness that they are using public space. The public space here should be interpreted as a free and neutral zone, where the dynamics of life take place personally and free from state, market and collectivism. Therefore the media, argues Ashadi Siregar (1985), must imagine the public as individuals who have autonomy and independence (cited in Abrar, 2011, p. xix). The media must not dictate to the public what they have to do. The media must provide a place for public discussion about various public issues. From an emerging consensus, audiences can make sense of their lives.

Second, the media can be a factor in the formation of the mind of the audience. The media can encourage audiences to have the power to respond to state power, especially state policies. The media can also be stimulated to be able to deal with the power of capitalism, especially the economic value it contains. The media can even have a strong position when dealing with the power of communalism (Abrar, 2011, pp. 12-13).

\section{Methodology}

Based on the above explanation, the concept of research was compiled consisting of the quality of news and accountability of the media. To assess the quality of the news, the author used the assessment in Table 1.

As for assessing press accountability, the author used the assessment in Table 2.

Referring to the characteristics of the news that supports the above narrative, the author conducted a content analysis of 20 news stories. The author defined the six special characteristics of the message. The author collected news that had been sent by the Public Relations Bureau of Central Java Province. The news was published between 1 July 2016 and 31 August 2016. The titles of the 20 news items analysed are listed in Table 3.

Actually, all of these news items were filed by participants of the 2016 


\begin{tabular}{|c|l|l|l|}
\hline \multicolumn{3}{|c|}{ Table 2: Press accountability assessment sheet } \\
\hline No. & \multicolumn{1}{|c|}{ Aspect } & Comment & Writing in paragraphs \\
\hline 1 & $\begin{array}{l}\text { The press seems to have a public space, } \\
\text { which is a free and neutral zone, where } \\
\text { the dynamics of life take place personally } \\
\text { and free from state power, markets and } \\
\text { collectivism. }\end{array}$ & & \\
\hline 2 & $\begin{array}{l}\text { The press can be seen as a factor in the } \\
\text { formation of the mind. }\end{array}$ & & \\
\hline
\end{tabular}

journalism competition held by the Public Relations Bureau of Central Java Province. The winner, according to Biro Humas Provinsi Jawa Tengah-Public Relations Bureau of Central Java Province (2016b), can be seen in Figure 1 on page 250. This figure shows that the author is one of the judges in the journalism competition. As a jury, the author delivered the results of the author's assessment to the Public Relations Bureau of Central Java Province. This assessment (Abrar, 2016) can be seen in Figure 2 on page 251.

There is a striking difference between the contents of Figure 1 and the contents of Figure 2. In Figure 1, the first winner Lis Retno Wibowo, while in Figure 2 he only occupies fifth place. In Figure 1, the second winner is Joko Suroso, while in Figure 2 he occupies sixth place. In Figure 1, the third winner is Wisnu Adi Nugroho, while in Figure 2 he is not ranked. Why is there such a striking difference?

The answer can be seen through the results of the research below. The news theme is 'Half time of Ganjar-Heru leads Central Java'. However, 'participants could specify more specific sub-themes that support the main theme in accordance with the conditions in their respective coverage areas' (Biro Humas Provinsi Jawa Tengah-Public Relations Bureau of Central Java Province, 2016b). With this kind of provision, news topics would be very diverse.

The concept of research compiled consists of the quality of news and accountability of the press. Articles that have been collected were then analysed by using two criteria: news quality and media accountability.

News quality criteria are: 1) The tendency of the news to be concentrated on the government officials reported was not on the issue being reported; 2) the impression that the information reported was obtained by journalists in a very easy way; 3 ) news that is broadcast contains information that stands alone; and 4) news coverage stops with officials as resource persons without trying to find a deeper meaning from unofficial sources.

Press accountability criteria are: 1) the media seems to have a public space, which is a free and neutral zone, where the dynamics of life take place personally and free from state power, markets and collectivism and 2) the media can be seen as a factor in the formation of the mind. 


\begin{tabular}{|c|c|c|}
\hline No. & News title & Posted by \\
\hline 1 & $\begin{array}{l}\text { Mimpi jalan mulus mulai terwujud } \\
\text { (The dream of a smooth street begings to realise) }\end{array}$ & $\begin{array}{l}\text { Sugie Rusyono, } \\
\text { Suara Merdeka }\end{array}$ \\
\hline 2 & $\begin{array}{l}\text { Bunga hanya } 7 \% \text {, jadi solusi permodalan UMKM } \\
\text { (Interest only } 7 \% \text {, becomes a capital solution for MSME) }\end{array}$ & $\begin{array}{l}\text { Andika Parabowo, Koran } \\
\text { Sindo Jateng }\end{array}$ \\
\hline 3 & $\begin{array}{l}\text { Pengentasan kemiskinan jadi pertaruhan } \\
\text { (Alleviating poverty becomes betting) }\end{array}$ & $\begin{array}{l}\text { Amin Fauzi, } \\
\text { Koran Sindo Jateng }\end{array}$ \\
\hline 4 & $\begin{array}{l}\text { Separuh waktu Ganjar-Heru memimpin Jawa Tengah: menem- } \\
\text { bus Ketidakwajaran (Half-time of Ganjar-Heru leads Central } \\
\text { Java: penetrating impropriety) }\end{array}$ & $\begin{array}{l}\text { Joko Suroso, } \\
\text { Magelang Ekspres }\end{array}$ \\
\hline 5 & $\begin{array}{l}\text { Ciptakan daya tarik hindari kota mati } \\
\text { (Create attraction avoid dead cities) }\end{array}$ & $\begin{array}{l}\text { Surya Yuli Purwariyanto, } \\
\text { Suara Merdeka }\end{array}$ \\
\hline 6 & Nilai rapor Ganjar 75 (Value of Ganjar report card 75) & SN, Wawasan \\
\hline 7 & $\begin{array}{l}\text { Gotong-royong, kucurkan kredit murah } \\
\text { (Mutual cooperation, offer cheaper credit) }\end{array}$ & $\begin{array}{l}\text { Lis Retno Wibowo, } \\
\text { RadarSemarang.com }\end{array}$ \\
\hline 8 & $\begin{array}{l}\text { Kartu tani, antara as a dan was-was } \\
\text { (Farmers cards, between hope and worry) }\end{array}$ & $\begin{array}{l}\text { Hermiana E Effendi, } \\
\text { AntaraJateng.com }\end{array}$ \\
\hline 9 & $\begin{array}{l}\text { Perlu kebersamaan dalam pengentasan kemiskinan } \\
\text { (Need to be together in poverty alleviation) }\end{array}$ & $\begin{array}{l}\text { Wisnu Adhi Nugroho, } \\
\text { AntaraJateng.com }\end{array}$ \\
\hline 10 & $\begin{array}{l}\text { Staf kebengungan saat Ganjar Pranowo memotret sampah } \\
\text { (Staff confused when Ganjar Pranowo photographed trash) }\end{array}$ & $\begin{array}{l}\text { M. Nur Huda, } \\
\text { Tribun Jateng }\end{array}$ \\
\hline 11 & $\begin{array}{l}\text { Separuh perjalanan Ganjar-Heru manahkodai Jateng: } \\
\text { Pahlawan demi mewujudkan mandiri energi } \\
\text { (Half time of Ganjar-Heru leads Central Java: Heroes for the } \\
\text { sake of realising energy independent) }\end{array}$ & $\begin{array}{l}\text { Arie Widiartu, } \\
\text { Suara Merdeka }\end{array}$ \\
\hline 12 & $\begin{array}{l}\text { Kredit mitra, bukti keberanian gubernur sediakan pinjaman } \\
\text { murah pada masyarakat (Partner credit, proof of courage } \\
\text { governor provides cheap loans to the community) }\end{array}$ & $\begin{array}{l}\text { LAU, } \\
\text { Metrojateng.com }\end{array}$ \\
\hline 13 & $\begin{array}{l}\text { "Jateng gayeng" wujud nyata resistensi Jawa Tengah ("Central } \\
\text { Java delights" the real form of Central Java resistance) }\end{array}$ & $\begin{array}{l}\text { Bambang Isti, } \\
\text { Suara Merdeka }\end{array}$ \\
\hline 14 & $\begin{array}{l}\text { Kisruh pabrik semen menunggu kebijakan "sakti" Ganjar } \\
\text { (Chaotic cement factory awaits Ganjar's "magic" policy) }\end{array}$ & $\begin{array}{l}\text { Nazar Nurdin, } \\
\text { Kompas.com }\end{array}$ \\
\hline 15 & $\begin{array}{l}\text { Mendongkrak produktivitas warga Karimunjawa } \\
\text { (Boosting productivity of Karimunjawa residents) }\end{array}$ & $\begin{array}{l}\text { Zakki Amali, } \\
\text { Serat.id }\end{array}$ \\
\hline 16 & $\begin{array}{l}\text { Milyaran dana mangkrak di koperasi bermasalah korban } \\
\text { terpuruk dan sengsara (Billions of stalled funds in troubled } \\
\text { cooperatives damaged and miserable victim) }\end{array}$ & $\begin{array}{l}\text { Budiyono, } \\
\text { Kilas Fakta }\end{array}$ \\
\hline 17 & $\begin{array}{l}\text { Berharap Jawa Tengah makin gayeng } \\
\text { (Hoping Central Java to be more colorful) }\end{array}$ & $\begin{array}{l}\text { Eko Susanto, } \\
\text { Sindo Jateng }\end{array}$ \\
\hline 18 & $\begin{array}{l}\text { Menggali potensi desa untuk mengentaskan kemiskinan } \\
\text { (Exploring the potential of villages to eradicate poverty) }\end{array}$ & $\begin{array}{l}\text { Puji Purwanto, } \\
\text { SuaraMerdeka.com }\end{array}$ \\
\hline 19 & $\begin{array}{l}\text { Lepas dari jerat rentenir, kembali percaya pada Bank } \\
\text { (Free from creditor trap, back to trust in the Bank) }\end{array}$ & $\begin{array}{l}\text { Ajie Mahendra, Jawa Pos } \\
\text { Radar Semarang }\end{array}$ \\
\hline 20 & $\begin{array}{l}\text { Lebih banyak introspeksi } \\
\text { (More introspection) }\end{array}$ & \begin{tabular}{|l} 
GPE, \\
Tribunjateng.com
\end{tabular} \\
\hline
\end{tabular}




\section{Winners of 2016 Journalistic Competition of Public Relations Bureau of Central Java Province Theme: Half time of Ganjar-Heru leads Central Java}

On this day, Monday, the third of October of 2016, a journalistic competition for written journalists (print and online) has been conducted, which was held by the Public Relations Bureau of Central Java Province, with the theme 'Half Time of Ganjar-Heru Leads Central Java', located in the Meeting Room of the Regional Secretariat of the Central Java Province, Building A 11th Floor, Office of the Governor of Central Java, with juries: (i) Amir Machmud, (ii) Ana Nadhya Abrar, and Sunaryo. The aspects assessed: (i) objectivity and balance, (ii) depth and completeness, (iii) accuracy, and (iv) how to deliver the news.

The juries agreed that there were three winners of the competiton. They were: Lis Retno Wibowo from Jawa Pos Radar Semarang as the first winner, Joko Suroso from Magelang Ekspres as the second winner, and Wisnu Adhi Nugroho from antarajateng.com as the third winner

Figure 1: Winners of the Central Java PR journalism competition, 2016.

\section{Results and discussion}

Results:

\section{News concentration:}

The result shows that only 6 news items (30 percent) concentrated on the issue. While the rest (70 percent) concentrated on government officials. This shows that journalists are still focused on the speech of officials. They are not interested in reporting issues.

\section{How to get facts:}

Following the data on the concentration of the news above, it appeared that journalists got the facts easily, by interviewing government officials reported. The number of news included in this group reached 14 news items ( 70 percent). The rest, as many as 6 items (30 percent) obtained facts by conducting coverage in the field.

\section{Position information in the news:}

Most of the news (13 items - 65 percent) contains stand-alone information. It is not related to similar issues in the past and present. Only seven news items (35 percent) contain information related to the past and present. This shows that journalists are not interested in delivering comprehensive information. What are the consequences? Audience is not helped to understand the current connection with past events. They also cannot imagine the present connection with 


\section{Reading news about Half time of Ganjar-Heru leads Central Java Province}

Quantitatively, the author assessed 20 news items sent by 20 written journalists. From this assessment, he selected six journalists who became the top six, namely: Amin Fauzi (345), Mukhamad Nur Huda (340), Ari Widarto (335), Nazar Nurdin (335), Lis Retno Wibowo (335) and Joko Suroso ( 335). However, he doubts the judgment, because the format of the news is not the same. There are many hard news items. There are many soft news items. There are also many features. The difficulty level of writing each news item is different, even though he did not consider this level of difficulty.

The interest of the Public Relations Bureau of Central Java Province to hold a journalistic competition is certainly not just to excite journalists who are in the bureau to write news about Central Java, but also to educate them to write news in accordance with journalism obligations and rights. The first and foremost obligation of journalism, acording to Bill Kovach and Tom Rosenstiel in their book, The Elements of Journalism, is to serve the truth (2014, p. 12). Starting from this obligation, it emerged that one of the logics of journalism was to check and recheck. So check and recheck become a tool to convince us that the facts gathered are truth.

However, this truth is not included in the criteria that form the basis of the assessment set by the Public Relations Bureau of Central Java Province.

While the right of journalism is to broadcast/publish news in accordance with the news values that it adhere to. What are these values? First, news items must present facts that answer the $5 \mathrm{~W}+1 \mathrm{H}$ questions (what, who, where, when, why and how). If the facts presented do not answer these five questions, the news cannot be called news.

Second, a news item must fulfill the news values set by the media concerned. As a result, a media will not report news items that do not contain news values.

The fact criteria problem that answers the $5 \mathrm{~W}+1 \mathrm{H}$ question is already represented by depth and completeness. However, about the amount of news values, it has not been included in the Public Relations Bureau of Central Java Province as the basis for the assessment.

Starting from here, my assessment cannot fully be a picture of the true quality of news journalism about the journey of Half Time of Ganjar-Heru Leads Central Java Province. It can only be a proxy for the quality of journalism. The result, of course, is legal.

With this situation, I leave the final assessment to the Public Relations Bureau of Central Java Province about who will be the winner of this competition.

Yogyakarta, 2 October 2016 Ana Nadhya Abra

Figure 2: Reading the news about 'half time in Central Java', 2016. 
the future. Even though this understanding will make it easier for people to put themselves in the changes that have occured.

\section{News coverage stopped at:}

Most of the news (14 items - 70 percent) stopped at officials as resource persons. The rest, six news items (30 percent) tried to find other sources who were not government officials. Most journalists did not want to find a deeper meaning from the events or ideas reported

\section{Relation to free public sphere:}

Most of the news (14 items-70 percent) did not include sources other than government officials, especially the Governor of Central Java, Ganjar Pranowo, in the news investigated. Only 6 news items (30 percent) included the opinions of ordinary people in the news reported. This situation, caused by the media that broadcast/publish the news, did not encourage the creation of a free and neutral public space that could show the dynamics of a free life. The resource persons who were government officials dominated the dynamics of life reported.

\section{Relation to the formation of rational minded people:}

Most of the news (14 items-70 percent) broadcast information sourced from government officials, especially the Governor of Central Java, Ganjar Pranowo. This information dominates the news. Even though there are six news items (30 percent), that broadcast the opinions of ordinary people, that opinion cannot defeat the opinions coming from government officials. When viewed as a whole, the audience still cannot form a rational mindset.

\section{Discussion:}

\section{Journalism competition}

The journalism competition for journalists who are members of the 2016 Press Club of Public Relations Bureau of Central Java Province is the third such competition. The first competition, as documented in the book Ganjar Controversy, began in 2014. As a prize, the winning journalists were sent for a trip to Germany. The book then quotes the following Ganjar statement, 'I have rewards for those who win the competition because they are part of the process of accelerating, motivating, and contributing to the development of Central Java' (NS, 2016).

This quote shows that Ganjar, in his position as Governor of Central Java, was very appreciative of the role of journalists. For him, journalists helped him build Central Java. Naturally, he then sent journalists who won journalism competitions for a trip to Germany.

However, there are parties who object to Ganjar's attitude. For example, the Independent Journalists Alliance (AJI) Semarang. NS in the book Ganjar Controversy documented this objection in the following: 


\begin{abstract}
AJI openly refused to send journalists to Germany. AJI suspects this step as a form of concession to some journalists who are considered to have helped. It is more unfortunate that the objections to Germany are suspected of using public funds. 'The provincial government is not a party that is obliged to provide journalist training, let alone use public funds to go to Germany,' said Rofiuddin, chair of AJI (2016, pp. 176-177).
\end{abstract}

The quotation above shows that AJI Semarang did not want journalists to be coopted by the Central Java Provincial Government. AJI Semarang wanted journalists who are members of the Press Club in the Public Relations Bureau of the Central Java Province to remain free and independent. However, Ganjar was unmoved. He still dispatched journalists who were the winners of the journalism competition in the 2014 Public Relations Bureau of Central Java Province to go to Germany. NS stated the explanations in Ganjar Controversy as follows:

Responding to the criticism and refusal, the PDI-P politician actually continued to disperse, but with a diplomatic tone he stated that everything was left to journalists. If all journalists declare that they have not departed, then this policy is canceled. (2016, p. 177).

This explanation shows that Ganjar did not care about what would happen to journalists. What is important for him was, all the programmes ran smoothly. Indeed, he never demanded that journalists be a member of the Press Club of the Public Relations Bureau of Central Java Province to help him build Central Java. However, every journalist in the Press Club tried to write the best news, according to the jury.

For Sunaryo, one of the judges in the journalism competition, holding a journalism contest is the way the Public Relations Bureau of Central Java Provincial Governement encourages journalists. 'To enlarge the spirit of the winners in covering news about Central Java,' added Sunaryo (Personal communication, October 2, 2016).

The effort to please the journalist was seen in the recognition of the winners of the journalism competition. The first winner, Lis Retno Wibowo, said that he was very happy to be the first winner. He highlighted the idea of openness practiced by Ganjar. He said Ganjar helped encourage information transparency in the Central Java regional government. In this case, Ganjar uses social media to obtain information from the public. Through social media, the community can interact with it. 'Regardless of whether the community complaints will be followed up later or not, the community is happy to be able to communicate with their leaders,' Lis added (Personal communication, March 29, 2019).

The second winner, Joko Suroso, has the same opinion as Lis Retno Wibowo. He said there were many changes in the leadership of Ganjar-Heru, especially the 
complaints process that was so easy and fast, it could be through social media. All regional work units are asked to provide easy services, make social media for complaints or provide development information. 'The people are increasingly facilitated to meet with their leaders. I am satisfied with Ganjar's performance, Joko added (Personal communication, March 29, 2019).

The third winner, Wisnu Adi Nugroho, also had a similar opinion to the other two reporters above. He said that Ganjar and the ranks had even slept in people's homes and held discussions to listen to their complaints. Ganjar also made a Whatsapp group and distributed numbers for discussions with the public and journalists. 'So I am satisfied with the information disclosure that Ganjar has shown,' Wisnu added (Personal communication, March 30, 2019).

The explanation above shows that the three winners of the journalism competition agreed with Ginanjar's policy, encouraging information disclosure in Central Java Province. They did not see the results of this openness, whether or not they solved the problems faced by the community. They even feel satisfied with that openness. In this context, they actually praised Ginanjar. With this praise they get the reward-winning the journalism competition

Looking further, it seems not too excessive to state that the journalism competition held by the Central Java provincial public relations bureau has attempted to tame reporters. This conclusion makes sense, because there are conflicts between journalists and Ganjar. This conflict, has actually emerged since Ganjar Pranowo was appointed Governor of Central Java on 23 August 2013. Since then, he has shocked various parties. By implementing the principle of 'Mboten Korupsi-Mboten Ngapusi'('No Corruption-No Lie'), he has broken down the establishment of the Central Java Regional Government bureaucracy that he had been requested to serve. He also stopped aid for journalists. Regarding this last factor, Isdiyanto stated:

Starting from the issue of termination for a number of journalist communities and journalist organisations. This included the policy of eliminating 'envelopes' as transport coverage of the Central Java Provincial Government and thousands of government social assistance for educational and religious institutions also led to polemics. (Isdiyanto, 2016, p. viii)

\section{The rhetoric of Ganjar}

According to Ganjar, his own view is that since becoming Governor he has tried to respect journalists. One way is to remove the reporter's envelope. He stopped giving out envelopes containing transport money coverage that had been provided by the Public Relations Bureau of Central Java Province. He decided on this after evaluating the structure, performance and budget execution of the Public Relations Bureau of Central Java Province. NS documented Ganjar's comments 
about this in the book Ganjar Controversy:

I have indeed heard information about giving money. At that time, I saw many journalists coming in and out of the public relations room, so I asked what was this? They answered, 'As usual, sir, take the money out of coverage'. 'Wow, is this true,' asked Ganjar at the time. (2016, p. 141)

Ganjar's comments are, of course, true. Ethically journalists are forbidden to accept bribes. This prohibition is officially written in Article 6 of the Journalism Code of Ethics: Indonesian journalists do not abuse the profession and do not accept bribes.

The interpretation of this article, as documented in the book by Abrar entitled Governance of Political Journalism is as follows:

a. Abusing a profession is any action that takes personal advantage of information obtained while on duty before the information becomes general knowledge.

b. Bribes are gifts in the form of money, objects or facilities from other parties that affect independence (Abrar, 2015, pp. 92-93)

However, Ganjar's attitude was considered as abuse of journalists. This assessment was recorded by NS in the book Ganjar Controversy as follows:

Mentioned, the Governor's statement that had admitted that removal of journalists' envelopes was a form of harassment of the journalist profession. Some accused Ganjar of being influenced by one of the journalist organisations which had been strongly voicing opposition to giving envelopes to journalists, while others suspected revenge by the removal of journalists who supporting one of the governor candidates. However, there are also those who expressed support for the steps that actually glorify the journalist profession (2016, p. 142)

By positioning the journalism competition as an arena to assess the performance of the relations between the Central Java provincial government and journalists, in fact there has been mismanagement. The Provincial Government of Central Java does not educate journalists to be independent and free, but promises prizes for journalists who are considered to be reporting on events or around Central Java that are good in terms of relations between the two parties. Without being directed, journalists will certainly broadcast good news. They will not be eager to broadcast bad news, although the news substance is criticising the government.

Then an absurd condition is created. The press, which has been the watchdog of the government, has been changed to obey the government. The press, said Ade Armando had lost an important political role (2005, p. xi).

In the political sphere, such relations between the press and government, according to Margaretha Selu Kushendrawati invites both things, namely: 1) 
abuse of power by the government; and 2) the press is being used as a means to calm the public (2007, p. 86).

Ganjar is indeed consistent with his idea of journalism competitions. Until 2016, he continued to hold such competitions. If this competition continues to be carried out with improvements for the benefit of journalists, of course the results will be good. Ganjar will get high appreciation from journalists and the public.

However, in organising the 2016 journalism competition, important improvements in the elements of news assessment have not been carried out. The results of this research show that the truth and the amount of news values has not been included in the criteria that are the basis of the assessment set by the Public Relations Bureau of the Central Java Province. The main criterion of assessment is the relevance of the news with half time of Ganjar-Heru leads Central Java. Actually, behind this criterion there was the hope that journalists report news about the success of Ganjar-Heru leads Central Java.

It is not surprising if the journalist who is a member of the Press Club of the Public Relations Bureau of the Central Java Province has metamorphosed into a servant of the bureau. This attitude as a servant has been demonstrated by the results of this study.

From a cultural point of view, said Deddy Mulyana, a member of the Press Club of Public Relations Bureau of Central Java Province did not want to criticise Ganjar because of the influence of the element of paternalism. 'In addition, the element of collectivism (prioritising groups rather than individuals and maintaining harmony) also plays an important role,' Deddy added (Personal communication, March 25, 2019).

So what does this have in relation to the lives of journalists? Journalists betray their position in society. The position of journalists in society, according to Siregar is to contribute to human civilisation. He said:

Journalism activities contain intellectual actvities. They will maintain insights related to civilisation. Therefore, a journalist should be aware that his professional activities contribute more or less to the growth of his community's culture. $(1985$, p. 9$)$

Following this fact, it is not exaggerating if the author interprets that the mission of the Journalism Bureau of Public Relations of the Central Java Province is to establish Ganjar as the Governor of Central Java. This mission is reflected in most of the news that participated in the journalism competition. Indeed every news item, said Dahlan Iskan, must have a mission. However, the mission is not to establish government officials, but to educate and motivate the community for good (as cited in Intarto, 2013, p. 126).

\section{Conclusion}


It could be assumed that Ganjar Pranowo would be happy to read the news that followed the journalism competition in the 2016 Public Relations Bureau of Central Java Province. However, the results of the above research showed that the Press Club had a bad atmosphere. Journalists as press professionals have pawned their freedom in writing news about the Central Java Provincial Government. This attitude hurts the reputation of journalists. Journalists handed over the accountability of news to Central Java provincial officials.

Indeed, the Public Relations Bureau of Central Java Province never directed journalists who were members of the Press Club to write favourably about the Central Java Provincial Government. However, the existence of a journalism competition which was created as a venue to assess the relationship performance with the Central Java provincial government meant journalists were unconsciously co-opted. The element of paternalism and collectivism also shape the attitude of journalists. They seem to be able to be winners if they write favourable news about Central Java Province. They then compete to write news that is liked by Central Java provincial officials, especially the governor.

Indeed journalists feel happy just following the journalism competition. They even feel that being a winner can actually be a step to please by the Public Relations Bureau of Central Java Province. However, they have actually been trapped making themselves no longer autonomous and free. As a result, the journalists are no longer watchdogs of the Central Java Provincial Government. They have turned into pet poodles.

\section{References}

Abrar, A. N. (1997). Bila fenomena jurnalisme direfleksikan (If the phenomenon of journalism is reflected). Jakarta, Indonesia: Pustaka Sinar Harapan.

Abrar, A. N. (2011). Analisis pers: Teori dan praktek (Press analysis: Theory and practice). Yogyakarta, Indonesia: Cahaya Atma Pustaka.

Abrar, A. N. (2015). Tatakelola jurnalisme politik (Governance of political journalism). Yogyakarta, Indonesia: Gadjah Mada University Press.

Abrar, A. N. (2016). Reading news about 'Half time of Ganjar-Heru leads Central Java province'. An assessment report as a jury of journalistic competition of Public Relations Bureau of Central Java Province.

Armando, A. (2005). Kata pengantar (Foreword). In D. Schechter, Matinya media: Perjuangan menyelamatkan demokrasi (The death of media: The fight to save democracy). Jakarta, Indonesia: Yayasan Obor.

Asano, O. (1996). The Nippon Kisha Club Stays Active. (in The Japanese Press 1996). Tokyo, Japan: Nihon Shinbun Kyokai.

Aziz, T. (1992). Politik redaksional Surabaya Post: Produk media. (Surabaya Post editorial politics: Media products). Surabaya, Indonesia: Surabaya Post.

Biro Humas Provinsi Jawa Tengah (2016a). Pemenang lomba jurnalistik bagi wartawan tulis oleh Biro Humas Provinsi Jawa Tengah (The winner of the journalistic competition for written journalists by the Public Relations Bureau of Central Jawa Province). Semarang, Indonesia: Pemda Provinsi Jawa Tengah. 
Biro Humas Provinsi Jawa Tengah. (2016b). Lomba karya jurnalistik bagi wartawan tulis oleh Biro Humas Provinsi Jawa Tengah (Journalistic competition for write journalists by the Public Relations Bureau of Central Java Province). Semarang, Indonesia: Pemda Provinsi Jawa Tengah.

Dickinson, R. \& Memon, B. (2012). Press club, the journalistic field and the practice of journalism in Pakistan. Journalism studies, 13(4), 616-632.

Intarto, J. (2013). Akal sehat Dahlan Iskan: Catatan seorang murid (Common sense of Dahlan Iskan: A student, note). Yogyakarta, Indonesia: Adiwacana.

Isdiyanto (2016). Merekam dinamika kepemimpinan Ganjar (Recording the dynamics of Ganjar leadership). In A. M. NS (Ed.), Kontroversi Ganjar (Ganjar controversy). Jakarta, Indonesia: Penerbit Buku Kompas.

Ismail, A., \& Ismail, R. (2017). Knowledge versus experience: Indicator to good journalism practices. Malaysian Journal of Communication, 33(4), 142-158.

Kovac, B., \& Rosenstiel, T. (2014). The elements of journalism: What newspeople should know and the public should expect. (Third edition). London, UK: Penguin Random House.

Krause, M. (2011). Reporting and the transformations of the journalistic field: US news media, 1890-2000. Media, Culture and Society, 33(1), 89-104.

Kuga, K. (2016). Japan's press clubs: An impregnable fortress of information. Media Asia, 43(1), 14-17.

Kushendrawati, M. S. (2007). Media massa dan kekuasaan: Sebuah refleksi etika (Mass media and power: A reflection of ethics). Respons, jurnal etika sosial (Journal of social ethics), 12(2), 84-93.

NS, A. M. (Ed.). (2016). Kontroversi Ganjar (Ganjar controversy). Jakarta, Indonesia: Penerbit Buku Kompas.

Siregar, Ashadi (Ed.). (1985). Profesi wartawan di mata saya (Professional journalists in my eyes). Yogyakarta, Indonesia: LP3EY.

UNESCO Series on Journalism Education (2013). Model curricula for journalism education: A compendium of new syllabi. Paris, France: UNESCO.

Ana Nadhya Abrar is a senior lecturer in journalism at Gadjah Mada University (GMU), Yogyakarta, Indonesia. He started out with a bachelor's degree in mass communication (at GMU), before he went on to study environmental journalism at York University, Toronto, Canada, where he completed his master's degree (MES) in 1994. In 2010, he completed his doctorate in journalism at the University of Malaya, Kuala Lumpur, Malaysia. He has written widely on political journalism, business journalism, and establishing the scientific resources for journalism education. Among his Indonesian-language books are: Wading the Relationship Between the Indonesian Parliament and the Government during Megawati Soekarnoputri's Presidency through Journalism (2014), Governance of Political Journalism (2015), Scrutinising the Future of Indonesian Journalism (2016), Business Journalism: The Awakening Stage and Business Instincts (2017), and Journalism Ethics (2018). 
The author would like to thank the Public Relations Bureau of Central Java Province for giving him the opportunity to become a judge in the 2016 journalism competion held by the bureau.

ana.abrar@mail.ugm.ac.id

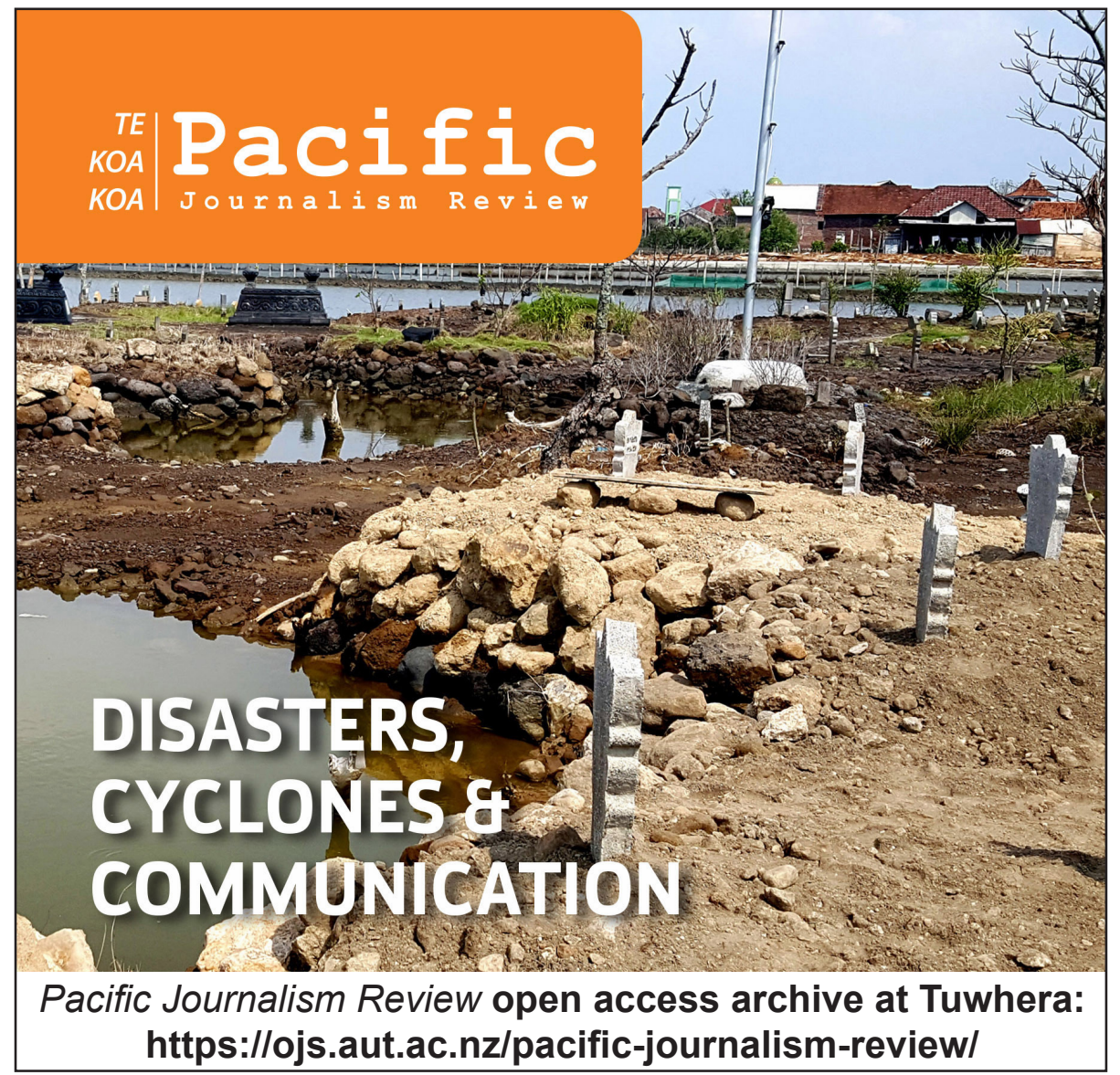

